\title{
Strengthening of Local Micro Business Legal (UMKM) Law Regulation in Requiring Sustainable Tourism in Bali
}

\author{
I Ketut Gde Suarnatha and Ida Bagus Wyasa Putra \\ Faculty of Law, Universitas Udayana, Denpasar, Bali-Indonesia \\ pasupatiassociate8@gmail.com
}

Published: 28/02/2020

How to cite: Suarnatha, I. K. G., \& Putra, I. B. W. 2020. Strengthening of Local Micro Business Legal (UMKM) Law Regulation in Requiring Sustainable Tourism in Bali. Sociological Jurisprudence Journal. 3(1). 43-53. https://doi.org/10.22225/ scj.3.1.1515.43-53

\begin{abstract}
Sociological study of local MSMEs in facing various obstacles in their growth and development and juridical studies related to the legal basis underlying the need to strengthen the competitiveness of local MSMEs in Bali. This research aims to analyze the factors that affect the competitiveness of local micro, small and medium enterprises (MSMEs) in organizing the trade in tourism services in Bali. This research used is normative research method. This research uses several approaches including: conceptual approach, philosophical approach and analytical approach. The results of this study showed that the formulation of strengthening the competitiveness of local micro, small and medium enterprises (MSMEs) in organizing the tourism services trade in Bali is based on the principle of fair efficiency and the principle of subsidarity so that local MSMEs can become new entities that reflect the philosophy of Tri Hita Karana and have strong competitiveness realize sustainable tourism. It is recommended to the Provincial Government of Bali, to make efforts to crystallize the value of local wisdom that can be applied as the identity of local MSMEs, so that there are formal standards in determining local MSMEs as a new entity in the economic world.
\end{abstract}

Keywords: Legal arrangements, Local Micro, Small and Medium Enterprises, Sustainable Tourism and Bali

\section{INTRODUCTION}

Strengthening and empowering MSMEs is very much determined by the internal factors of MSMEs, which are related to the ability of MSMEs in increasing productivity, increasing human resources, improving management capabilities and increasing market access so that they are able to compete in the development of the global economy. MSMEs also play a very important role in the trade in tourism services which include various components of service trade, such as: business actors, forms of services, service consumers, and service transactions that connect service suppliers and service consumers (Putra, 2010).

Tourism activities in the era of globalization can't be denied has a positive impact in the form of economic benefits, such as: income from the tax sector and expansion of employment opportunities, especially for countries that are tourist destinations. But on the other hand, tourism can also have negative impacts, such as environmental damage, public order and cultural values that are the spirit of Indonesian tourism. The trade in tourism services involves various aspects. These aspects include economic, cultural, social, religious, environmental, security, and other aspects. The aspect that gets the most attention in tourism development is the economic aspect.

Tourism activities that involve large-scale businesses and Micro, Small and Medium Enterprises, hereinafter referred to as MSMEs, have a strategic role in national economic development, because besides having a role in economic growth and employment, it also plays a role in the distribution of development results. Micro, Small and Medium Enterprises as part of popular economic businesses are important to be empowered in the midst of the development of tourism. In organizing tourism in the era of globalization, the government needs to provide encouragement so that business activities in the 
tourism sector can provide opportunities in empowering the people's economy (Gelgel, 2006). If MSMEs as a form of populist economy are not given opportunities and are not empowered, then they will not have competitiveness when dealing with global economic forces.

Tourism liberalization certainly presents foreign businessmen or suppliers in Indonesia which generally can be classified as large-scale businesses (Widiatedja, 2011). With the leap in technology, unlimited funding (capital) and qualified skills, it would certainly not be fair if they would later compete with MSMEs that make up the largest portion of business forms in Indonesia (Widiatedja, 2011). The government, as a representation of the welfare state, is certainly obliged to protect the existence of MSMEs so that they are not eliminated in their own countries. It is important to know, what is faced by MSMEs is not only big foreign business actors, but also big domestic players with strong capital. In order to improve competitiveness, MSMEs need to strengthen their capital structure by opening as many opportunities as possible to get access to business capital.

The Government and Regional Governments empower and provide financing and guarantees by increasing working capital financing, access to finance through the capital market, other financial institutions and developing credit guarantee institutions. What is regulated in several Articles of the MSME Law above does not clearly and explicitly regulates the role of the Government and Regional Governments in providing capital for MSMEs. The issue of access to funding or capital should be part of business development that needs to be clearly and operationally regulated. The MSME Law has not responded in real terms to how easily MSME has access to capital or finance by considering the characteristics of MSME itself.

Sociologically the problem faced by MSMEs is that the government still lacks maximum attention towards MSMEs, especially with regard to strengthening and empowering internally from MSMEs themselves. Many deregulation products actually sacrifice entrepreneurs in the MSME category, both directly and indirectly, even though these entrepreneurs in various events actually become the main drivers of social power (Pakpahan \& Limahelu, 1992). Capital is the key to running a business, because without capital it is not possible for MSMEs to run the business they want. The phenomenon faced by MSMEs is not only related to capital, but also weak in terms of human resources, technology, management, and market access, making it difficult to compete and partner with large businesses (Hafsah, 2000).

Considering that there are some facts in the community that show that MSMEs in the field of tourism are marginalized and unable to compete with large businesses, namely:

a. Street vendors and acoustic traders of the MSME group selling handicrafts that are being chased by Satpol PP when holding their wares in front of or around the Artshop, which incidentally belongs to big business actors. Here certainly needs to be questioned about the policies or policies of the Regional Government in regional economic development which often discusses the slogan "community base tourism" or community-based tourism and community economic development. Acung traders and street vendors should have facilitated their market access by providing a place of business for them, so that those involved can enjoy economic progress due to the influence of tourism.

b. The mushrooming of Artshop or souvenir shops that sell all kinds of souvenirs and local specialties, even more recently in 2018, Bali was stirred by the existence of "illegal" souvenir shops from China Bamboo Curtain Country. Their existence has clearly killed traditional markets and art markets which generally consist of MSMEs. Responding to this phenomenon, what needs to be questioned is regarding the partiality of the Regional Government, which is clearly still a big business actor. Local governments and big businessmen pay less attention to the interests of the community, which in general consists mostly of MSMEs.

c. The condition of allowing hotels to make themselves as an exclusive place provides all the needs of tourists, ranging from food, souvenirs, clothing and others, so that almost no dime of tourist money can be enjoyed by MSMEs. The question is why a hotel as a place to stay is at the same time as a place of trade by seizing land where traditional community businesses work. This condition is contrary to the principle of "community base tourism" (Sutjipta, 2005).

The facts mentioned above show how weak the position of MSMEs is in developing themselves to be 
able to compete with other companies in the tourism services trade. Strengthening and empowering local investment (MSMEs) has been carried out both by the central government and regional governments both in the form of regulations and policies to strengthen MSMEs both regarding capital access, market access, access to technology use and other policies that are strengthening MSMEs such as the issuance of the Act - The UMKM facilitates access to capital through Government Banks, besides that the government has issued a partnership policy pattern between MSMEs and SOEs both in market access and technology access, but in reality MSMEs have not been able to develop themselves in the face of competition with companies - other big companies.

The existence of the MSME shows that the inability of local MSMEs to compete with large companies in the trade in tourism services lies in the internal inability of MSMEs themselves. The inability of MSMEs includes the inability to improve the quality of good quality Human resources, quality of management, quality of products, quality of use of technology, information finding market access and the absence of new innovations from MSME itself. These things will be the subjects of study in this study. So that this research can be expected to find solutions, both normatively and in implementation, so that the strengthening of local MSMEs can be carried out and able to compete with other companies in the tourism services trade.

Especially in the discussion on "organizing tourism in Bali" it can be understood that the soul/spirit that enlivens tourism in Bali is culture. It is undeniable that culture grows and develops in the behavior and daily lives of local people, so it is logical that "the implementation of tourism in Bali" must be systematic, coordinated and planned by paying attention to how efforts to keep culture in Bali growing and maintained towards suistanable tourism.

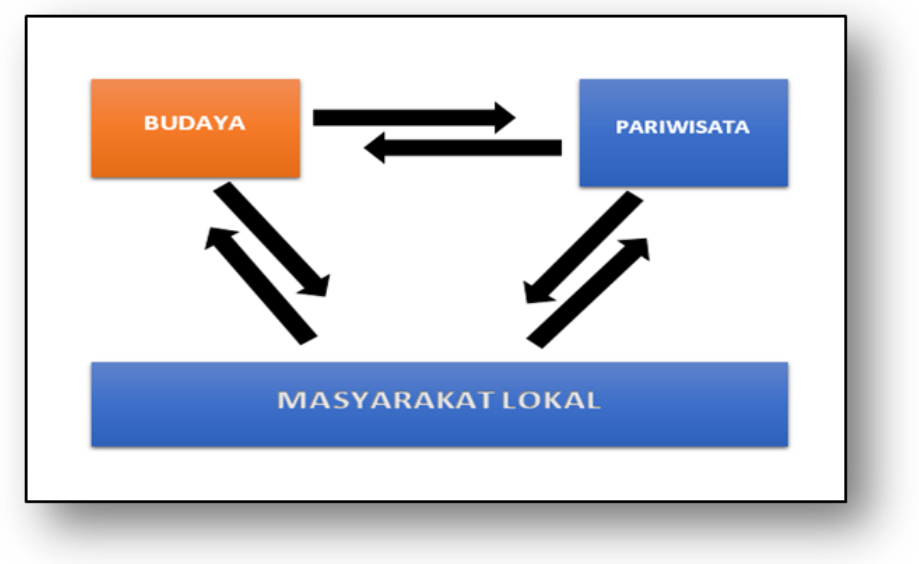

Figure 1

Tourism organizing chart in Bali

Moving on from the above description, there are two issues that form the basic points in this research, there are; culture created in local people's behavior patterns needs to be maintained to create sustainable tourism (Suistanable Tourism) and Local people should be one of the stakeholders in realizing sustainable tourism (Suistanable Tourism, many local communities have businesses in the form of MSMEs hoping to obtain economic impact from the organization of tourism but this has not yet received attention in the form of legal rules (regulations) that pay attention to the interests of the community local. Referring to the conditions above, this research aims to analyze the factors that affect the competitiveness of local micro, small and medium enterprises (MSMEs) in organizing the trade in tourism services in Bali.

\section{METHOD}

This research used is normative research method. Considering that in the regulation of MSMEs there has not been any attention to arrangements regarding local MSMEs, especially in the tourism service business. This research uses several approaches including: conceptual approach, philosophical approach and analytical approach. The legal materials were obtained through document study techniques by inventorying legislation related to local MSMEs and tourism service businesses. The collected legal 
materials were then analyzed using a number of methods including: description analysis, interpretation, evaluation and argumentation techniques.

\section{RESULT AND DISCUSSION}

\section{Local Micro, Small And Medium Enterprises (MSMES) As a New Entity}

Economic actors or business people, both individuals and institutions that have the goal of making a profit, drive the national economy. Economic actors carry out economic activities by using various forms of business, and running businesses that also vary (Imaniyati, 2009). This was revealed by Hartono opinion which states Economic actors essentially carry out the economic activities of the community. Economic actors consist of individuals and institutions that are commercially intended as business entities or corporations. Economic activities are carried out in various scales and various forms of activities. These activities can include either in the form of production (goods and or services), trade (goods or services), or intermediaries, both on a national and international scale (Hartono, 2000).

Besides varying in the form of business, type of business, and scope of business, economic actors also vary greatly in their existence in national law and the position of the institution. Regarding this matter, Hartono revealed Economic actors in Indonesia are essentially very varied, both regarding their existence in regulations, activities and institutional positions. At the lower strata, for example, it consists of individual economic actors with relatively limited capital strength. In the middle and upper strata, several forms of business entity are found, both non-legal entities that have legal entity status (Hartono, 2013).

According to Sri Redjeki Hartono, that in society there are economic activities carried out by economic actors or business actors with limited capital strength, such as Micro, Small and Medium Enterprises (MSMEs) and economic actors or large business actors with large capital strength. The Indonesian economy in SMEs is a business group that has a large number. Regarding MSMEs in Indonesia, it is regulated through Law No. 20 of 2008. The regulation shows the attention of the Indonesian government in controlling and overseeing one of the pillars of the national economy. The provisions of article 1 numbers 1, 2, and 3 provide the following definitions of MSME:

a. Micro Business is a productive business owned by individuals and / or an individual business entity that meets the criteria for micro business in accordance with the law.

b. Small Business is a productive economic business that stands alone, which is carried out by individuals or business entities that are not subsidiaries or non-branch companies that are owned, controlled or become a part either directly or indirectly of medium-sized businesses or large businesses that meet the criteria of small businesses as regulated in law.

c. Medium Business is a productive economic business that stands alone, which is carried out by individuals or business entities that are not subsidiaries or branch companies that are owned, controlled, or become part either directly or indirectly with small businesses or large businesses with a total net worth or annual sales results as provided for in the law.

The definition or limitation of Micro, Small and Medium Enterprises (MSMEs) is reinforced in the provisions of Article 6 of Law Number 20 Year 2008 concerning the criteria of Micro, Small and Medium Enterprises (MSMEs). The MSME concept in general has been explained before. Indeed, this country realizes that economic growth is highly dependent on the strengths of MSMEs. Economic growth is an effort to increase production capacity to achieve additional output, which is measured using Gross Domestic Product (GDP) and Gross Regional Domestic Product (GRDP) in an area (Ismayanti, 2010). Economic growth is a process of changing the economic conditions of a country that is sustainable towards better conditions for a certain period (Tarigan, 2005).

The economic growth of a region will be greatly influenced by several factors. There are three main factors that influence the economic growth of a society, namely (Arsyad, 2010): Capital accumulation, with capital used today is expected to produce something more in the future; Population growth, more population will have an impact on the amount of labor supply as well as increasing the potential of the domestic market; The use of technology, with the technology being continuously updated will facilitate various aspects of life. With the right technology, it certainly will affect the economic growth of the 
community.

The formation of law must be avoided the occurrence of context problems. Context problems in the process of legal formation can take the form of: law is different from community expectations, the law ignores community expectations; law is against community expectations, coercion, pressure, and urges community expectations, or to a higher degree, the law damages, destroys, and excludes community (Putra, 2016), so that the concept of local MSMEs must be adhered to.

The word 'local' has often been said and associated with cultural elements. If seen the meaning of the word 'local' in the Big Indonesian Dictionary describing 'somewhere, local, happening somewhere' (Anonim, 1996). As an example sentence, 'the quality of local textile production is no longer inferior to foreign production'. The sentence explains that the local word is the product of a local product which originally from a certain place. Many things can be associated with the use of this local word, especially in nouns. For example, 'local cloth, local rice, local car, local sickle, etc.', the local word affirms that whatever is something that is purely from somewhere.

The concept of a local MSME is a concept where the MSME actors are local residents of an area, not migrants who inhabit a certain area then form MSMEs with a local label. This cannot be said to be a local MSME. As said before where the SMEs must be local residents in an area.

Local residents are a group of people who live or inhabit a certain area and are subject to all applicable rules and also take into account local wisdom in their area. If someone arrives or is known as a migrant population occupying a certain area and forms an MSME but they are not subject to and obey the rules that apply in that area, then that MSME cannot be referred to as a local MSME.

The migrant population is residents who come from outside the area that he occupies or domicilates. These migrants respond to local residents (Barclay, 1984), of course social interaction will occur in the community. The definition of local MSME based on the previous explanation can be concluded as a business that meets the MSME criteria as determined by law and was established by local residents and having the address in the area where he is domiciled. Empowerment of local MSMEs is urgent and must be realized by the government immediately. The government should focus more attention on empowering local MSMEs to be independent and able to stand on their own. This empowerment can be done by facilitating the marketing of local products as well as providing guidance and direction to the local SMEs.

The problem of Micro, Small and Medium Enterprises (MSMEs) is a very interesting problem to be studied scientifically, because Micro, Small and Medium Enterprises (MSMEs) are part of the economic order of the Indonesian people (Suhardi, Makarao, \& Fauziah, 2012). The important role of Micro, Small and Medium Enterprises (SMEs) as one of the pillars of the Indonesian economy began to be recognized and considered since the crisis hit Indonesia (Ikhsan, 2004). At least there are two important roles of Micro, Small and Medium Enterprises (MSMEs) that are quite significant are their contributions in investment and providing employment opportunities (Ikhsan, 2004). For this reason, the existence of Micro, Small and Medium Enterprises (MSMEs) can support the Indonesian economy. Looking at the economy in Indonesia, most of the nation's economic sectors are in the Micro, Small and Medium Enterprises (SMEs). In fact the nation's economy is more reliant on small and medium industries that are very large in number, while the large industries are not so numerous.

Organizations formed to achieve the will interests and common goals become a unity or entity (entity [England], entiteit [Netherlands]) in the association between people. Therefore also, if humans as an entity in the association of humans need the right to protect their interests, so does the organization as other entities in the association between people, also requires rights.

The granting of rights by law will put the non-human entity as another legal subject in addition to humans. In turn, the granting of this right provides an opportunity for this organization to carry out actions in the association of society, both legal and non-legal. Considering that each party's rights will always be faced with the obligations of other parties, and vice versa, this legal entity does not only provide rights, but also legal obligations, as is the subject of law. Then, the entity that was transformed into the subject of this law in the field of legal science is known as the standard term "legal entity" (Rido, 2004) which is a body or entity that is legally recognized, has rights and obligations.

Relevance in the context of local MSME talks, so whether the form of local MSMEs, both CV, firm, 
and UD also insofar as they are still identified in the local MSMEs, the forms of reinforcement initiated in this study are incorporated in a single local MSME strengthening system to become a right can be obtained (local legal / MSME subjects). Looking back at the entity, in theory, this idea was introduced in 1243 by Sinibald Fieschi, who later became Pope Innocent IV (1243-1254), which stated that the company was "a persona ficta" (Dewey, 1926).

The legal personality of an entity other than humans is the result of a fiction. According to Von Savigny, only humans have the will. Because it is not human, the entity (company) cannot become a real human being as a human being and cannot have a personality itself. Furthermore, Von Jhering revealed that according to von Jhering, the concept of the Company's personality is indispensable and solely an economic tool to facilitates the tasks that connect legal relations. Therefore, if necessary, the law must look at the background of the entity to find out the actual affairs.

In line with the principle of Lifting (or Piercing) of the Corporate Veil which reveals the right is not an attribute contained in human will and thus an individual is not the subject of rights on the grounds that he has a will. On the contrary, the will is a legal service and is in the interests of those protected by law. The subject of rights is not owned solely by humans but also by every thing that has the will or will and lives on its own. Thus, becoming a juristic person and being "alive" as humans, then a company also has rights. A company exists as an objectively real entity and the law also recognizes it and gives it consequences for its existence.

Various opinions confirm that the law does not have the power to create an entity, but only has the right to recognize or not recognize an entity (Ghadas, 2007). Speaking in the context of this research, the forms of reinforcement summarized in the formulation of written regulations (Perda) are intended for MSMEs in the sense that what is intended in terms of "local MSMEs" is "local / local communities" in an economic perspective. As explained in the previous section that standardized business actors in the form of local MSMEs are people who carry out business activities in the form of CV, firm or UD business entities, which in the trade of tourism services require special treatment in the form of systems involving various stakeholders.

Local MSMEs to be able to become a legal entity in the economic field must of course have characteristics both an identity. Which through the introduction of the characteristics and characteristics of local MSMEs can be distinguished between local MSMEs with MSMEs in general as stipulated in the legislation. Identity is an essence that can be interpreted through signs of taste, trust, attitude and lifestyle. Identity is considered both personal and social and indicates that "we are the same or different from others" (Kumbara, 2012). A person's identity can be judged by gender, race, ethnicity, language, nation, religion, and even the way he is dressed. In identifying or assessing an identity in a way, identifying nature, identifying the characteristics of humans and identifying culture. An optional element for identifying one's identity is culture. In general, cultural culture is all human thoughts and behaviors that are functionally and dysfunctionally arranged in their society" (Koentjaraningrat, 2005). According to Chris Jenks in (Surjawa, 2014) culture is a medium that connects humans and nature. Culture exists because humans exist. Culture is meaningful only if the nature, which is the cause of the birth of that culture, still exists in an identity quality that is equivalent to the condition when the culture was created. Stuart Hall in (Erniwati, 2011) divides cultural identity into two different definitions, namely:

First, cultural identity is related to equality in a particular group in which its members share a common history and common ancestry. Cultural identity in this definition, illustrates the similarity of historical experience and various cultural symbols that make them a stable, unchanging community and continue the terms of reference and meaning under historical change. Second, the definition of cultural identity is the identification formed by history and cultural elements. Cultural identity here then contains political identity, namely the politics of positioning in certain societies (Erniwati, 2011).

Cultural identity as a representation is not permanent because of incomplete production or construction, but always in the process of change and formed from within the group. According to Aristotle in (Kleinman, 2013) identity is defined as whatever makes an entity recognizable. All entities have specific characteristics and qualities that allow one to define and distinguish them from other entities, which has the meaning of identity as whatever makes an entity (truly exist) identifiable. All entities have characteristics and qualities that allow one to determine someone, to determine a characteristic or definition and distinguish them from the others. 
As we know, Balinese culture cannot be separated from factors, nature, history and beliefs. Most Balinese are Hindu. As many as 3.2 million Indonesian Hindus live in Bali, and the majority adheres to the Hindu beliefs of the Shiva-Buddhist sect, making it different from Indian Hindus. Priests from India who traveled in the Archipelago introduced Hindu-Buddhist literature to the Balinese tribe centuries ago. Society accepts it and combines it with pre-Hindu mythology they believe. The Balinese, which existed before the third wave of migration, known as the Bali Aga, mostly adhered to different religions from the Balinese in general. They maintain the animist tradition. The existence of Balinese belief is inseparable from the interference and support of the Dutch government, some naturalists, Balinese elites and the people of the Netherlands. The colonial government banned missionaries from operating in Bali in 1881. In 1924, the Roman Catholic mission to Bali was rejected by the Balinese elite and colonial officials supported it. In addition, Dutch Protestant missionaries who wanted to enter Bali in 1931 were also opposed. Bali is also famous for its dance, performance art and sculpture. Covarrubias observed that every Balinese deserves to be called an artist, because there are various art activities that they can do apart from their busy lives as farmers, traders, coolies, drivers, etc. - from dancing, playing music, painting, sculpting, singing, to play play. Even in a dilapidated village one can find beautiful temples, reliable gamelan players and even talented actors. Even offerings made by Balinese women have an artistic side to the interwoven pieces of coconut leaves and a neat and towering arrangement of fruits.

In line with that, the existence of local people who do business (UMKM) to become an entity must be strengthened by their identity in terms of nature (nature and topography) as well as their culture and elements of belief. Adhering to the theory of "Receptio In Complexu" which was coined by Salomon Keyzer and Van Den Berg who stated that if a community becomes a follower of a particular religion, then the customary law is the religious law that it adheres to. Receptio In Complexu's theory considers customary law to be accepted unanimously (fully) from the religious law adopted by the community (Muhammad, 1961). When this theory is applied in the life of the Balinese people, it is found that little or much the pattern of Balinese life is influenced by Hindu religious beliefs.

Discussing Hindu religious beliefs at the level of ethics and behavior, there is a belief that has firmly rooted in people's lives that are believed to be ideal values in realizing harmony in life. It is the concept of "Tri Hita Karana". The concept of Tri Hita Karana originates from the teachings of Hinduism. Donder revealed that the Tri Hita Karana concept could be seen from the aspect of tourism management on the island of Bali in the concept of Hinduism (Donder, 2007). Tri Hita Karana is the three causes of the relationship of balance and harmony between humans and Ida Sang Hyang Widhi Wasa / God Almighty (Parahyangan), between humans and others (pawongan), and between humans and the natural environment (palemahan) (Wirata, 2015).

The depth of the Tri Hita Karana concept as mentioned above is certainly in line with the ecological concept, which is the concept that forms the basis for environmental protection and preservation. The environment cannot be separated from efforts to develop national tourism. So it cannot be denied that the concept of Tri Hita Karana should be a cultural identity that is held as one of the local MSME standards. So this effort becomes harmonious with efforts to develop national and Balinese tourism based on culture and the environment. Technically in the regulation of MSMEs, standards can be applied that refer to the characteristics and characteristics that use the Tri Hita Karana concept, such as:

a. Aspects of "Parahyangan" such as: lighting incense in a room or place used to provide tourism services, making construction or Balinese architectural styles of buildings used to carry out tourism services, etc.

b. Aspects of "Pawongan" such as: saying "Om Swastyastu" or "suksma" in communicating to do tourism services, communicating using Balinese on certain days (Purnama, Tilem and Thursday), using gambling or fun music on one of the instruments tourism services.

c. Aspects of "Palemahan" such as: using flower facilities in the creation of a place or atmosphere in the administration of tourism services, placing living plants in certain parts for creative and aesthetic purposes, using natural-smelling facilities such as soil, leaves or tree trunks on objects that are used for facilities or creations, etc.

Certainly the various Balinese cultural identities can be applied to MSMEs that are registered as local MSMEs. To be registered as a local UMKM in its arrangement, it can be required to be registered in 
advance at the local village head/Kelian Desa Adat which The village list of local MSMEs will be accepted by the Village / Headman. Following the standard is being referred to as local MSMEs, it can be arranged more technically in the derivative rules or implementing rules of the formulated Regional Regulation (Perda).

\section{Local Micro and Small Medium Enterprises (MSME) legal arrangements in terms of value perspective}

Legislation should be based on important foundations, namely philosophical foundations, sociological foundations, juridical foundations, political foundations and design techniques foundation (Modeong, 2003). The purpose of making laws and regulations is for order and legitimacy, which considers competence (Utsman, 2010). The requirements for the entry into force of the law as a rule include:

a. The rule of law applies juridically, if the determination is based on a higher-level rule or is formed on a predetermined basis.

b. The rule of law applies sociologically, if the rule is effective. That is, the authorities can enforce the rule even though it not accepted by the citizens (the theory of power) or the rule applies because of the recognition of the community.

c. The rule of law applies philosophically, which is in accordance with the ideals of the law as the highest positive value (Ali, 2010).

As a comparative material is explain related issues of legal validity or legal validity. The basic conception of Weber's opinion is related to the legal consequences for society. Whether a rule of law provides benefits to the community or not, with this measure, the drafters of the Regional Regulation must be able to abstract the objectives of the regional regulation. If in practice later, the Regional Regulation is ineffective then the designer's goal in enforcing the rule of law can be declared a failure.

Based on the opinion of normative or formal applicability, the substance of the perda will be related to two important questions. First, the local regulation does not conflict with higher regulations. Second, whether the substantive regulation does not conflict with other local regulations. By using this thinking, the legislators will be careful to carefully examine every rule of law related to the regulations that are formed. This parallelization of typology is Weber's second thought about the validity of law at the Jurisprudence level, namely internal consistency of law with its own rules and principles.

Explaining this stage of consistency, a new rule of law has its validity if it is based on a higher principle vertically and horizontally on the substance of the local regulation. If in a regulation of there are provisions that contradict the higher rules, the regulation can be declared as an invalidity of law. Consequently, the local regulation can't be applied properly and thus the regulation loses its binding power because invalidity causes the loss of the obligation for the community to obey it (the principle of legality; / legaliteit beginsels) (Ali, 2010).

Evaluative use of validity thinking rests on the thought of a legal rule based on its content must have value on an empirical and philosophical level. To determine the nature of these values can be seen from empirical and philosophical aspects. A local regulation is a provision whose substance is well received by the community (does not cause turmoil in society). Therefore, local regulations must be able to be sure to set a matter that is true (truth) not justification (justify) alone. Then, this section will be closely related to the conception of "consistency of law with external ethical or moral values." This conception will provide easy guidelines for the formation of local regulations, namely whether the regulations are contrary to the moral values of the people or not.

In general, the essence of development is full human development and the development of the whole community. The essence of this development implies that national development achieves balance, harmony and harmony between outward progress and inner satisfaction. Sustainable national development aims to improve the quality of life of the nation, so that it is always able to realize the tranquility and well being of inner and outer life. Every society always has a "rechtsidee" which is what is expected from the law, for example to guarantee justice, order, welfare, and so on. This rechtsidee or legal ideal grows out of a system of values about good and bad, views about individual relationships and society, about material things, and so on. All of that is contrary to philosophical, which means to argue 
about the essence or essence of something.

The philosophical foundation is the foundation relating to the basis or ideology of the state, namely the values (ideals of law) contained in Pancasila. In this context, the values (legal ideals) contained in Pancasila can be observed in the Preamble to the 1945 Constitution, in the fourth paragraph:

Then rather than that to form an Indonesian Government that protects all Indonesian people and all Indonesian blood spills and to advance public welfare, educate the nation's life, and participate in carrying out world order based on independence, eternal peace and social justice, the Indonesian National Independence was drafted. In the Constitution of the Republic of Indonesia, which is formed in the composition of the Republic of Indonesia, which is sovereignty of the people based on the Almighty God, humanity that is just and civilized, Indonesian Unity and Popularity led by wisdom in Consultation/Representation, and with realizing a social justice for all Indonesian people.

In accordance with Article 33 Paragraph (4) of the 4th Amendment of the 1945 Constitution of the Republic of Indonesia, it is stated the national economy shall be implemented based on economic democracy with the principles of togetherness, equitable efficiency, sustainability, environmental insight, independence, and by maintaining a balance of progress and national economic unity.

The context of modern thought about justice in the Indonesian dictionary the term justice comes from the word fair, meaning that it is impartial, rightly, not arbitrary. So justice is defined as an attitude or just action. In English literature the term justice is referred to as "justice", essentially the word "juice". The word "jus" means law or rights. Thus one of the notions of "justice" is law.

The meaning of justice as law then develops the meaning of the word "justice" as "lawfullness" which is legal validity. Another notion attached to justice in a broader sense is "fairness" which is commensurate with worthiness. Fair character in the sense of worth or proper, can be seen from the terms used in the science of law. For example "priciple of fair play" which is one of the general principles of good governance, "fair wage" is defined as a decent wage that is often found in terms of labor law. The same thing was stated in the concept of justice Aristotle that he called "fairness in human action" justice is the feasibility of human action.

When examined more deeply, justice as part of social values has a very broad meaning, even at some point it can be contrary to the law as one of the social values. The measurement of justice as mentioned above actually reaches the ideal area or is within the realm of mind, because it talks about the issue of justice, it means that it is already within the realm of meaning that falls within the philosophical level that requires deep reflection to the innermost essence, even Hans Kelsen emphasizes philosophy Plato's law, that justice is based on knowledge about something good. Knowledge of the good is fundamentally a problem outside the world so it is clear that justice enters into philosophical studies.

Many philosophies expect inspiration for the knowledge of justice. Including the fields of philosophy that are very different in space and time. Justice is one example of material or form, which is the object of philosophy. In the study of philosophy, justice has been a serious subject since the beginning of Greek philosophy. Justice talks have a wide range, ranging from those that are ethical, philosophical, and legal, to social justice. Many people think that acting fairly and unfairly depends on the strength and strength they have, to be fair is quite easy, but of course this is not the case in human life. Justice becomes an inseparable part of the aims of the law itself, in addition to legal certainty and expediency. Responding to some legal issues that occur in the country of Indonesia, which then set forth in a number of judges' decisions so as to bring to a human knowledge. Justice is abstract, in the world of philosophically growing in the human realm of human life, but it cannot be denied that all people crave justice. Underlying this, the efficiency of justice referred to in the Constitution became the driving force for a series of efforts to implement MSME empowerment by prioritizing efficient efficiency in an effort to create a fair, conducive business climate and have a high level of competitiveness.

Law in axiological context is expected to reflect the justice value system both as a means of protecting values and as a means to realize it in people's behavior. In this context, it certainly aims to create a local MSME business climate that is fair, conducive and has a high level of competitiveness. These values are left in the community so that any formation of laws or regulations must be able to catch them every time they will form laws or regulations so that what is the purpose of the law (rechtidee) namely social justice for all Indonesian people can be achieved. 
Regarding the values of justice as described above are in line with the values in Hinduism as values inherent in local Balinese society:

"Icchanti devah sunvantam, Na svapnaya sprhayanti, Yanti pramadam atandra".

Meaning: the gods like those who work hard. The gods do not like people who laze. People who are always vigilant achieve great happiness. (Atharva Veda XX.18.3).

The noble values that develop in local communities in Bali are the soul that colors every movement of the community. In accordance with the above quote sloka, it can be described that the true community has a hard working and resilient soul as an obligation (swadarma) as a human being in the world. No human can live without acting (in the concrete sense: work). This noble value is then inherent in the work culture of the local community in Bali, which should be summarized in a conducive economic atmosphere and good access for local MSMEs to existing economic resources.

\section{CONCLUSION}

Based the results described above, thus it can be concluded that the legal regulation concerning local micro, small and medium enterprises (MSMEs) in organizing the trade of tourism services in Bali has an urgency to do. The strengthening of this regulation is based on the principle of just efficiency, which shows alignments towards harmony towards social welfare, and the principle of subsidiarity, namely the establishment of local scale authority. In addition, strengthening the competitiveness of local MSMEs begins with exploring the identity of local MSMEs that reflect the philosophy of Tri Hita Karana, considering that local MSMEs are a new entity in the world of tourism economy. Through this new identity, new rights that are intended to strengthen the competitiveness of local MSMEs in the world of tourism services trade are attached. Furthermore, it is recommended to the Provincial Government of Bali, to make efforts to crystallize the value of local wisdom that can be applied as the identity of local MSMEs, so that there are formal standards in determining local MSMEs as a new entity in the world of economy so that policies can be made at the regional level that specifically regulate Local MSMEs that include standardization and various forms of legal protection of local MSMEs.

\section{REFERENCE}

Ali, Z. (2010). Filsafat Hukum. Jakarta: Sinar Grafika.

Anonim. (1996). Kamus Besar Bahasa Indonesia, Edisi Kedua. Jakarta: Balai Pustaka.

Arsyad, L. (2010). Ekonomi Pembangunan, Edisi 5. Yogyakarta: Sekolah Tinggi Ilmu Manajemen Yayasan Keluarga Pahlawan Negara.

Barclay, G. W. (1984). Teknik analisa kependudukan jilid 2 (diterjemahkan oleh Rozy Munir dan Budiarto). Retrieved from http://ibrary.um.ac.id/free-contents/index.php/buku/detail/teknik-analisa-kependudukanjilid-2-george-w-barclay-diterjemahkan-oleh-rozy-munir-dan-budiarto-8806.html

Dewey, J. (1926). The Historic Background of Corporate Personality. Yale Law Journal, 35(6). Retrieved from https://www.jstor.org/stable/pdf/788782.pdf?seq=1

Donder, I. K. (2007). Kosmologi Hindu Penciptaan, Pemeliharaan, dan Peleburan Serta Penciptaan Kembali Alam Semesta. Retrieved from https://perpustakaan.iahntp.ac.id/index.php?p=show_detail\&id=1991

Erniwati. (2011). China Padang dalam Dinamika Masyarakat Minangkabau: dari Revolusi Sampai Reformasi. Retrieved from http://lib.ui.ac.id/file?file=pdf/abstrak-20306949.pdf

Gelgel, I. P. (2006). Hukum Pariwisata Suatu Pengantar. Denpasar: Universitas Hindu Indonesia.

Ghadas, Z. A. A. (2007). Real or Artificial? Jurisprudential Theories on Corporate Personality. US - China Law Review, 4(5). Retrieved from https:/heinonline.org/HOL/LandingPage?handle=hein.journals/ uschinalrw 4 div $=59 \& \mathrm{id}=$ \&page $=$

Hafsah, M. J. (2000). Kemitraan Usaha Konsepsi dan Strategi. Jakarta: Pustaka Sinar Harapan.

Hartono, S. R. (2000). Kapita Selekta Hukum Ekonomi. Retrieved from https://onesearch.id/Record/ IOS2862.UNMAL000000000030421

Hartono, S. R. (2013). Pengembangan Koperasi Sebagai Pelaku Ekonomi di Indonesia. Seminar Dan Lokakarya Pengembangan Hukum Nasional VIII. Denpasar.

Ikhsan, M. (2004). Mengembalikan Laju Pertumbuhan Ekonomi Dalam Jangka Menengah: Peran Usaha Kecil Dan Menengah. Jurnal Analisis Sosial, 9(2). Retrieved from https://www.neliti.com/id/publications/502/ mengembalikan-laju-pertumbuhan-ekonomi-dalam-jangka-menengah-peran-usaha-kecil-d

Imaniyati, N. S. (2009). Hukum Bisnis Tentang Telaah Pelaku dan Kegiatan Ekonomi. Retrieved from https:// 
catalogue.nla.gov.au/Record/4598185

Ismayanti. (2010). Pengantar Pariwisata. Jakarta: PT Raja Grafindo Persada.

Kleinman, P. (2013). Philosophy 101: A Crash Course In The Principles Of Knowledge, Reality and Values. United States of America: Adama Media.

Koentjaraningrat. (2005). Pengantar Antropologi pokok-pokok etnografi II. Retrieved from http://lib.ui.ac.id/ detail id $=20128642$

Kumbara, A. A. N. A. (2012). Wacana Antropologi: Membaca Ulang Teks Kebudayaan Menuju Transformasi Diri Dalam Multikulturalisme. Denpasar: Pustaka Larasan.

Modeong, S. (2003). Teknik Perundang-undangan di Indonesia, cetakan pertama. Jakarta: PT Perca.

Muhammad, B. (1961). Pengantar Hukum Adat: Djilid I. Jakarta: Ichtiar.

Pakpahan, N. S., \& Limahelu, F. (1992). Peta Hukum Dibidang Kegiatan Ekonomi, Suatu Studi Tentang Pembinaan dan Pengembangan Usaha Kecil dan Menengah pada Sepuluh Provinsi di Indonesia. Surabaya: Kantor Menko Ekuin dan Pengawasan Pembangunan bekerjasama dengan Fakultas Hukum Universitas Airlangga.

Putra, I. B. W. (2010). Fungsi Hukum Dalam Pengaturan Pariwisata Sebagai Bentuk Perdagangan Jasa: Inkonsistensi Konsep Dalam Kebijakan Pariwisata dan Penyerapan General Agreement on Trade in Services Dalam Pengaturan Perdagangan Jasa Pariwisata Internasional Indonesia. Program Doktor Ilmu Hukum Universitas Brawijaya.

Putra, I. B. W. (2016). Teori Hukum Dengan Orientasi Kebijakan (Policy Oriented Theory Of Law): Pemecahan Problem Konteks Dalam Proses Legislasi Indonesia. Retrieved from https://simdos.unud.ac.id/uploads/ file_penelitian_1_dir/0c2373eb74f0c1117b44b9f187b95527.pdf

Rido, A. (2004). Badan Hukum dan Kedudukan Badan Hukum Perseroan, Perkumpulan, Koperasi, Yayasan, Wakaf. Retrieved from http://lib.ui.ac.id/detail? id=33331

Suhardi, Makarao, T., \& Fauziah. (2012). Hukum Koperasi Usaha Mikro, Kecil dan Menengah di Indonesia. Retrieved from http://www.indeks-penerbit.com/index.php?route=product/product\&product_id=572

Surjawa. (2014). Ilmu Sosial dan Budaya Dasar. Retrieved from https://onesearch.id/Record/IOS3504.libra143061056

Sutjipta, N. (2005). Pariwisata Revolusi di Pulau Dewata. Denpasar: Universitas Udayana

Tarigan, R. (2005). Ekonomi Regional. Retrieved from https://opac.perpusnas.go.id/DetailOpac.aspx?id=349200

Utsman, S. (2010). Menuju Penegakan Hukum Responsif Konsep Philippe Nonet \& Philip SelznickPerbandingan Civil Law System \& Commom Law System Spiral Kekerasan \& Penegakan Hukum. Retrieved from http:// opac.ut.ac.id/detail-opac?id $=37602$

Widiatedja, I. G. N. P. (2011). Kebijakan Liberalisasi Pariwisata, Konstruksi Konsep Ragam Masalah dan Alternatif Solusi. Denpasar: Udayana University Press.

Wirata, K. (2015). Kebijakan Pengelolaan Wisata Ekoreligi Berkelanjutan: Berbasis Masyarakat Hukum Adat Bali. Retrieved from https://hukum.ub.ac.id/wp-content/uploads/2019/11/kebijakan-pengelolaan-wisata-ekoreligi -berkelanjutan-all.pdf 